\title{
Author Correction: Evolution and expansion of the RUNX2 QA repeat corresponds with the emergence of vertebrate complexity
}

\author{
Axel H. Newton (1) \& Andrew J. Pask
}

Correction to: Communications Biology https://doi.org/10.1038/s42003-020-01501-3, published online 15 December 2020.

In the original published version of the Article, the string of glutamines (QQQQ) in the Results section text "e.g., CAG CAA CAG CAA : QQQQ" was incorrectly bolded and underlined, changing the scientific interpretation of the text. The error has been corrected in the PDF and HTML versions of the Article.

Published online: 25 January 2021

\begin{abstract}
(c) (i) Open Access This article is licensed under a Creative Commons Attribution 4.0 International License, which permits use, sharing, adaptation, distribution and reproduction in any medium or format, as long as you give appropriate credit to the original author(s) and the source, provide a link to the Creative Commons license, and indicate if changes were made. The images or other third party material in this article are included in the article's Creative Commons license, unless indicated otherwise in a credit line to the material. If material is not included in the article's Creative Commons license and your intended use is not permitted by statutory regulation or exceeds the permitted use, you will need to obtain permission directly from the copyright holder. To view a copy of this license, visit http://creativecommons.org/licenses/by/4.0/.
\end{abstract}

(C) The Author(s) 2021 